\title{
PENGARUH STRUKTUR MODAL, PERTUMBUHAN PERUSAHAAN DAN UKURAN PERUSAHAAN TERHADAP NILAI PERUSAHAAN PADA PERUSAHAAN BARANG KONSUMSI YANG TERDAFTAR DI BURSA EFEK INDONESIA
}

\author{
EVELIN R.R SILALAHI ${ }^{1}$ \\ VHANNY A.P. SIHOTANG ${ }^{2}$ \\ Fakultas Ekonomi Program Studi Akuntansi Universitas Katolik Santo Thomas \\ evelinsilalahi37@gmail.com ${ }^{1}$,vhannysihotang@gmail.com ${ }^{2}$
}

\begin{abstract}
ABSTRAK
Penelitian ini bertujuan untuk menganalisis pengaruh pengaruh struktur modal, pertumbuhan perusahaan dan ukuran perusahaan terhadap nilai perusahaan pada perusahaan barang konsumsi yang terdaftar di Bursa Efek Indonesia. Populasi penelitian ini adalah semua perusahaan barang konsumsi yang terdaftar di BEI di tahun 2017-2019. Sampel pada penelitian ini didapatkan dengan cara purposive sampling, dengan jumlah sampel 39 perusahaan, dengan periode penelitian 3 tahun sehingga jumlah seluruhnya117. Hasil penelitian ini menunjukkan bahwa secara parsial (uji t), (1)struktur modal berpengaruh negatif dan tidak signifikan terhadap nilai perusahaan dengan tingkat signifikan 0,827 (2) pertumbuhan perusahaan berpengaruh positif dan signifikan terhadapnilai perusahaan dengan tingkat signifikan 0,048 dan (3) ukuran perusahaan berpengaruh positif dan signifikan terhadap nilai perusahaan dengan tingkat signifikan 0,000 . Hasil uji secara simultan (uji F) menunjukkan bahwa struktur modal, pertumbuhan perusahaan dan ukuran perusahaan berpengaruh positif dan signifikan secara simultan terhadap nilaiperusahaan pada perusahaan barang konsumsi yang terdaftar di Bursa Efek Indonesia.
\end{abstract}

Kata kunci : Nilai Perusahaan, Struktur Modal, Pertumbuhan Perusahaan dan Ukuran Perusahaan.

\section{PENDAHULUAN}

Semakin berkembangnya dunia usaha, semakin banyak pula perusahaan yang bermunculan sehingga menimbulkan persaingan yang ketat. Akibat persaingan yang ada membuat perusahaan semakin meningkatkan kinerja agar tujuannya dapat tetap tercapai. Tujuan utama perusahaan yang telah go public adalah meningkatkan kemakmuran pemilik atau para pemegang saham melalui peningkatan nilai perusahaan (Salvatore, 2005). Nilai perusahaan sangat penting karena mencerminkan kinerja perusahaan yang dapat mempengaruhi persepsi investor terhadap perusahaan (Brigham dan Houston, 2001).

Memaksimalkan nilai perusahaan sama dengan memaksimalkan nilai sekarang dari arus kas atau arus pendapatan yang diharapkan dan telah diterima oleh investor pada masa yang akan datang. Investor akan menilai perusahaan yang baik adalah perusahaan yang memiliki posisi keuangan yang baik.

Struktur modal mencakup mengenai keputusan pendanaan. Hal tersebut sangat penting bagi perusahaan untuk dapat menjalankan operasinya. Manajer dapat menggunakan utang sebagai sinyal yang lebih terpercaya untuk para investor. Ini karena perusahaan yang meningkatkan utang dapat dipandang sebagai perusahaan yang yakin dengan prospek perusahaan di masa yang akan datang. Jadi penggunaan utang merupakan tanda atau sinyal positif dari perusahaan yang dapat membuat para investor menghargai nilai saham lebih besar dari pada nilai yang tercatat pada neraca perusahaan, sehingga nilai perusahaan tinggi.

Pertumbuhan perusahaan akan mencerminkan bahwa perusahaan akan berkembang atau tidak. Pertumbuhan perusahaan adalah suatu rasio yang memperlihatkan kemampuan 
perusahaan untuk menjaga posisi ekonominya ditengah pertumbuhan perekonomian dan sektor usahanya (Suwardika \& Mustanda, 2017). Menurut Syardiana, Rodoni, \& Putri (2015) pertumbuhan perusahaan akan menghasilkan tingkat pengembalian yang semakin tinggi karena pertumbuhan memiliki aspek yang menguntungkan bagi pihak investor.

Menurut Brigham \& Houston (2010) ukuran perusahaan merupakan ukuran besar kecilnya sebuah perusahaan yang ditunjukan atau dinilai oleh total asset, total penjualan, jumlah laba,beban pajak dan lain-lain. Besar kecilnya ukuran perusahaan juga akan mempengaruhi perusahaan dalam kemudahan perolehan dana dari pasar modal, serta akan mempengaruhi kekuatan dari perusahaan dalam melakukan proses tawar menawar di dalam kontrak keuangan antar perusahaan.

Dari beberapa penelitian sebelumnya penulis ingin melakukan replikasi dari penelitian yang dilakukan oleh Saputri Dewi (2014), adapun perbedaan penelitian ini terletak pada variabel independen yang digunakan oleh Saputri Dewi yaitu struktur modal, pertumbuhan perusahaan dan profitabilitas, sedangkan penelitian ini mempunyai variabel independen struktur modal, pertumbuhan perusahaan dan ukuran perusahaan. perbedaan kedua adalah periode penelitian yang digunakan Saputri Dewi adalah tahun 2008-2012 sedangkan pada penelitian ini menggunakan periode tahun 2017-2018 dan perbedaan yang ketiga adalah Saputri Dewi meneliti perusahaan LQ 45 sedangkan pada penelitian ini meneliti perusahaan Manufaktur yang terdaftar di BEI.Berdasarkan latar belakang masalah yang telah dikemukakan diatas, maka yang menjadi identifikasi masalah dalam penelitian ini adalah teori yang mengatakan pengaruh struktur modal, pertumbuhan perusahaan dan ukuran perusahaan terhadap nilai perusahaan bertolak belakang dengan data yang ditemukan. Karena adanya ketidaksesuaian data dengan teori serta ketidakkonsistensi hasil peneilitian terdahulu, maka penulis ingin melakukan penelitian lanjutan tentang nilai perusahaan untuk melihat apakah hasil yang diperoleh nantinya akan memiliki hasil yang sama atau berbeda dengan penelitian yang dilakukan sebelumnya dan apakah penelitian mendukung teori yang ada.Berdasarkan penelitian tersebut dapat dirumuskan dengan masalah penelitian sebagai berikut "Apakah struktur modal, pertumbuhan perusahaan dan ukuran perusahaan berpengaruh terhadap nilai perusahaan pada perusahaan barang konsumsi yang terdaftar di Bursa Efek Indonesia periode2017-2019.

\section{TINJAUAN PUSTAKA DAN HIPOTESIS Struktur Modal}

Menurut Martono dan Agus (2001) struktur modal merupakan perbandingan atau imbangan pendanaan jangka panjang perusahaan yang ditunjukan oleh perbandingan hutang jangka panjang terhadap modal sendiri. Pemenuhan kebutuhan dana perusahaan dari sumber modal sendiri berasal dari modal saham, laba ditahan dan cadangan. Jika dalam pendanaan perusahaan yang berasal dari modal sendiri masih mengalami kekurangan maka perlu dipertimbangkan pendanaan perusahaan yang berasal dari luar yaitu dari hutang (debt financing).Struktur modal merupakan suatu masalah terpenting bagi perusahaan karena baik buruknya struktur modal akan mempunyai efek langsung terhadap posisi finanasial perusahaan, terutama dengan adanya utang yang besar akan menjadi beban yang besar bagi perusahaan.

Menurut Brigham dan Houston (2011) Sasaran struktur modal (optimal capital structure)suatu perusahaan didefinisikan sebagai struktur yang akan memaksimalkan harga saham perusahaan. Dari beberapa defenisi yang dikemukakan, dapat disimpulkan bahwa struktur modal merupakan proporsi keuangan antara utang jangka pendek, utang jangka panjang,dan modal sendiri yang digunakan untuk pemenuhan kebutuhan belanja perusahaan. Proxy yang digunakan untuk mengukur Struktur Modal menggunakan Rasio Leverage yang dimana dalam penelitian ini Rasio leveragemenggunakanDebtTo Equity Ratio(DER) 
Menurut Kasmir (2012) Debt to Equity Ratio (DER) menyatakan adalah rasio yang digunakan untuk menilai utang dengan ekuitas. Rasio ini berguna untuk mengetahui jumlah dana yang disediakan peminjam dengan pemilik perusahaan. rasio ini dicari dengan membandingkan antara seluruh hutang dengan seluruh ekuitas. DER lebih banyak digunakan oleh perusahaan dari pada menerbitkan DAR karena DER sangatberkaitan dengan hutang dan ekuitas struktur modal diukur dengan:

$\mathrm{DER}=\underline{\text { Total Debt }}$

\section{Total Equity}

\section{Pertumbuhan Perusahaan}

Pertumbuhan perusahaan merupakan kemampuan perusahaan untuk meningkatkan ukuran perusahaannya. Pertumbuhan (growth) adalah seberapa jauh perusahaan menempatkan diri dalam sistem ekonomi secara keseluruhan atau sistem ekonomi untuk industri yang sama Machfoedz (2007). Pertumbuhan perusahaan sangat diharapkan oleh banyak pihak baik internal maupun eksternal, karena pertumbuhan yang baik memberi tanda bagi perkembangan perusahaan. Pertumbuhan suatu perusahaan merupakan tanda perusahaan memiliki aspek yang menguntungkan, karena dianggap mampu menghasilkan keuntungan yang lebih baik dari waktu ke waktu.

Pada umumnya, perusahaan yang tumbuh dengan cepat akan memperoleh hasil positif, yang artinya akan dapat menguasai pangsa pasar dibandingkan dengan pesaingnya, mengalami peningkatan penjualan yang signifikan dan menjadi pesaing yang diperhitungkan. Pertumbuhan cepat juga memaksa sumber daya manusia yang dimiliki untuk secara optimal memberikan kontribusinya.

Pertumbuhan perusahaan adalah perbandingan total aset yang dimiliki perusahaan dengan tahun sebelumnya. Apabila jumlah total aset meningkat dibanding dengan tahun sebelumnya maka dapat dikatakan perusahaan tersebut mengalami pertumbuhan yang positif. Begitu pula sebaliknya apabila total aset mengalami penurunan maka perusahaan sedang dalam kondisi yang tidak baik. Dari sudut pandang investor, pertumbuhan perusahaan biasanya dilihat dari naiknya harga saham secara berkesinambungan dan pembagian dividen yang dilakukan perusahaan.

Dalam teori pertumbuhan perusahaan, dijelaskan ada lima tahap pertumbuhan perusahaan. Kelima tahap tersebut adalah tahap permulaan, tahap pertumbuhan, tahap kedewasaan, tahap stabil dan tahap penurunan. Pada tahap permulaan, perusahaan masih mencoba mengatur strategi dalam menjalankan perusahaan untuk mencapai tujuannya. Dengan demikian bila dihubungkan dengan return (hasil) maka perusahaan masih memperoleh return yang kecil karena belum mempunyai pangsa pasarnya sendiri. Tahap kedua adalah tahap pertumbuhan. Dalam tahap ini perusahaan sudah mulai dikenal dan mengalami kenaikan return disebabkan karena produk yang dihasilkan sudah dikenal masyarakat, namun banyaknya permintaan dan persaingan belum begitu ketat.

Tahap yang ketiga adalah tahap kedewasaan (mature). Pada tahap ini pertumbuhan perusahaan mulai menurun karena banyaknya pesaing yang mulai masuk dan permintaan cenderung stabil daripada mengalami kenaikan. Return yang dihasilkan kadang tinggi kadang juga mengalami penurunan. Tahap selanjutnya adalah stabil, yang merupakan tahap yang paling panjang dalam pertumbuhan perusahaan. Dalam tahap ini perusahaan dapat menghasilkan return dengan lebih stabil. Dan yang terakhir adalah tahap penurunan, yaitu tahap dimana pertumbuhan perushaaan semakin menurun karena semakin banyaknya persaingan industri sehingga return yang dihasilkan juga menurun bahkan tidak menutup kemungkinan akan negatif. Oleh karena itu pada tahap ini beberapa perusahaan mulai keluar dari industri dan mencoba melakukan diversifikasi ke produk lain yang lebih menguntungkan. Pertumbuhan perusahaan dapat dirumuskan sebagai berikut : 
Total Aset $(t)-$ Total Aset $(t-1)$

Total Aset $(t-1)$

\section{Ukuran Perusahaan}

Perusahaan merupakan suatu tempat untuk melakukan kegiatan proses produksi barang maupun jasa yang dilakukan secara terus menerus dalam kedudukan tertentu untuk mencari laba atau penghasilan. Ukuran perusahaan digunakan sebagai salah satu indikator mengenai seberapa besar perusahaan itu telah berkembang. Kadangkala sering dijumpai perbedaan antara perusahaan yang berskala besar dengan perusahaan yang berskala lebih kecil, sebagai contoh dalam hal kemampuan untuk mendapatkan dana atau modal.

Perusahaan yang besar umumnya memiliki fleksibilitas yang tinggi dalam masalah pendanaan melalui pasar modal, sehingga perusahaan besar memiliki kemudahan dan kemampuan lebih dalam mendapatkan dana. Perusahaan yang lebih besar cenderung memiliki sumber permodalan yang lebih terdiversifikasi, sehingga ukuran perusahaan merupakan proxy kebalikan dari kemungkinan kebangkrutan. Biaya menambah hutang dan modal sendiri juga berhubungan dengan ukuran perusahaan. Perusahaan kecil cenderung membayar biaya modal sendiri dan biaya hutang jangka panjang lebih mahal daripada perusahaan besar, sehingga perusahaan kecil mungkin menyukai hutang jangka pendek daripada meminjam hutang jangka panjang karena biayanya yang lebih rendah.

Menurut Brigham \& Houston (2010) ukuran perusahaan merupakan besar kecilnya sebuah perusahaan yang di tunjukan atau dinilai oleh total asset, total penjualan, jumlah laba, beban pajak dan lain-lain jadi ukuran perusahaan juga dapat diartikan sebagai keseluruhan kekayaan yang dimiliki oleh perusahaan baik dalam bentuk aktiva lancar maupun aktiva tetap. Ukuran perusahan dinyatakan dengan total asset, jika semakin besar total asset perusahaan maka akan semakin besar pula ukuran perusahaan tersebut.

Perusahaan yang relatif besar kinerjanya akan dilihat oleh publik sehingga perusahaan tersebut akan melaporkan kondisi keuangan dengan lebih berhati-hati, lebih menunjukan keinformatifan informasi yang terkandung didalamnya dan lebih sedikit melakukan manajemen laba, oleh karena itu semakin besar ukuran suatu perusahaan memiliki kualitas laba yang lebih tinggi karena tidak perlu melakukan praktik manipulasi laba dan sebaliknya. Pada dasarnya ukuran perusahaan hanya terbagi dalam 3 kategori, yaitu:

a. Perusahaan besar (large firm) adalah perusahaan yang memiliki kapitalisasipasar diatas 5 triliun.

b. Perusahaan menengah (medium firm) perusahaan dengan nilai kapitalisasi pasarnya antara 1 triliun samapi 5 triliun.

c. Perusahaan kecil (small firm) adalah perusahaan yang memilki kapitalisasi pasaryang kurang dari 1triliun.

Perusahaan yang memilki total aktiva besar menunjukan bahwa perusahaan tersebut telah mencapai kedewasaan dimana dalam tahap ini arus kas perusahaaan sudah positif dan dianggap memiliki prospek yang baik dalam jangka waktu yang relatif lama, selain itu juga mencerminkan bahwa perusahaan relatif lebih stabil dan lebih mampu menghasilkan laba dibanding perusahaan dengan total asset yang kecil.

Menurut (Pantow dkk, 2015) ukuran perusahaan dapat diproyeksikan dengan rumus sebagai berikut:

Size $=$ LN Total sasset 


\section{Nilai Perusahaan}

Menurut Harmono (2017), nilai perusahaan adalah kinerja perusahaan yang dicerminkan oleh harga saham yang dibentuk oleh permintaan dan penawaran pasar modal yang merefleksikan penilaian masyarakat terhadap kinerja perusahaan. Bagi perusahaan yang sudah go public, nilai perusahaan akan tercermin dari nilai pasarnya.

Menurut Sujoko dan Soebiantoro (2007) nilai perusahaan merupakan persepsi investor terhadap tingkat keberhasilan perusahaan yang terkait erat dengan harga sahamnya. Harga saham yang tinggi membuat nilai perusahaan juga tinggi, dan meningkatkan kepercayaan pasar tidak hanya terhadap kinerja perusahaan saat ini namun juga pada prospek perusahaan dimasa mendatang. Harga saham yang digunakan umumnya mengacu pada harga penutupan (closing price).

Berdasarkan pengertian -pengertian yang telah dikemukan diatas dapat disimpulkan bahwa nilai perusahaan adalah harga sebuah saham yang telah beredar di pasar saham yang harus dibayar oleh investor untuk dapat memiliki sebuah perusahaan go public. Nilai perusahaan tercermin pada kekuataan tawar menawar saham. Apabila perusahaan diperkirakan sebagai perusahaan yang mempunyai prospek yang bagus dimasa yang akan datang, nilai saham akan menjadi semakin makin tinggi.

Dalam pendirian perusahaan, tujuan perusahaan adalah memaksimalkan nilai pemegang saham. Nilai pemegang saham akan meningkat apabila nilai perusahaan meningkat yang ditandai dengan tingkat pengembalian investasi yang tinggi pada pemegang saham. Jusriani (2013) menyatakan nilai perusahaan yang tinggi menjadi keinginan para pemilik perusahaan, sebab dengan nilai perusahaan yang tinggi menunjukan kemakmuran pemegang saham juga tinggi.

Sujoko dan Soebiantoro (2007) menjelaskan factor-faktor yang mempengaruhi nilai perusahaan, yaitu:

1. Ukuran Perusahaan

2. Leverage

3. Kebijakan Deviden

4. Pertumbuhan Perusahaan

5. Struktur modal.

Dalam mengukur nilai perusahaan dalam penelitian ini penulis menggunakan rasio price Book Value (PBV) yang merupakan bagian dari nilai pasar yang dicapai dari tiap periode. Dipilihnya Price to Book Value untuk mengukur nilai perusahaan dalam penelitian ini karena Price to Book Value merupakan rasio yang sering digunakan untuk menentukan nilai perusahaan dan menggambil keputusan investasi dengan cara membandingkan harga per saham dengan nilai buku perusahaan. Harga pasar per saham disepakati penjual dan pembeli pada saat terjadinya transaksi per lembar saham. Sedangkan nilai buku per saham merupakan harga pada saat aktiva tersebut diperoleh per lembar saham.

$\mathrm{PBV}=\underline{\text { Market } \text { price per share }}$

Book value per share

\section{Kerangka Berpikir}

Dalam penelitian ini yang merupakan variabel independen adalah struktur modal, pertumbuhan laba dan ukuran perusahaan sedangkan variabel dependennya adalah nilai perusahaan. maka pengaruh struktur modal, pertumbuhan laba dan ukuran perusahaan terhadap nilai perusahaan pada perusahaan manufaktur dapat di jelaskan sebagai berikut: 


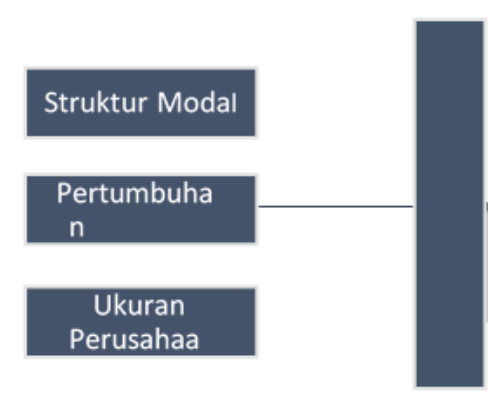

Keterangan:

$\mathrm{Y}$ : variabel dependen nilai perusahaanX1: variabel independen struktur modal

$\mathrm{X}_{2}$ : variabel independen pertumbuhan perusahaan $\mathrm{X}_{3}$ : variabel independen ukuran perusahaaan

\section{Hipotesis Penelitian}

Hipotesis adalah jawaban sementara dari suatu permasalahan yang dihadapi, yang kebenarannya masih perlu untuk dibuktikan lebih lanjut. Berdasarkan tinjauan teoritis rumusan masalah dan tinjauan penelitian terdahulu, maka hipotesis penelitian ini adalah sebagai berikut :

$\mathrm{Ha}_{1}$ : Struktur modal berpengaruh positif terhadap nilai perusahaan Ha2:Pertumbuhan perusahaan berpengaruh positif terhadap nilai perusahaan

Ha3: Ukuran perusahaan berpengaruh positif terhadap nilai perusahaan Ha4:Struktur modal, pertumbuhan perusahaan dan ukuran perusahaan berpengaruh positif terhadap nilai perusahaan

\section{METODE PENELITIAN}

Penelitian ini menggunakan teknik analissi regresi linier berganda karena variabel independen dalam penelitian lebih dari dua. Teknik analisis regresi linier berganda berguna untuk menguji hipotesis tentang kekuatan dua variabel atau lebih dan jugamenunjukan arah hubungan antara variabel bebas (Independen) terhadap variabel terikat (dependen). Teknik analisis data yang digunakan dalam penelitian ini adalah regresi linier berganda yang dilakukan dengan bantuan program pengelolaan data statistik yaitu SPSS. Berdasarkan mekanisme hubungan antar variabel maka formulasi matematis dalam penelitian ini adalah sebagai berikut:

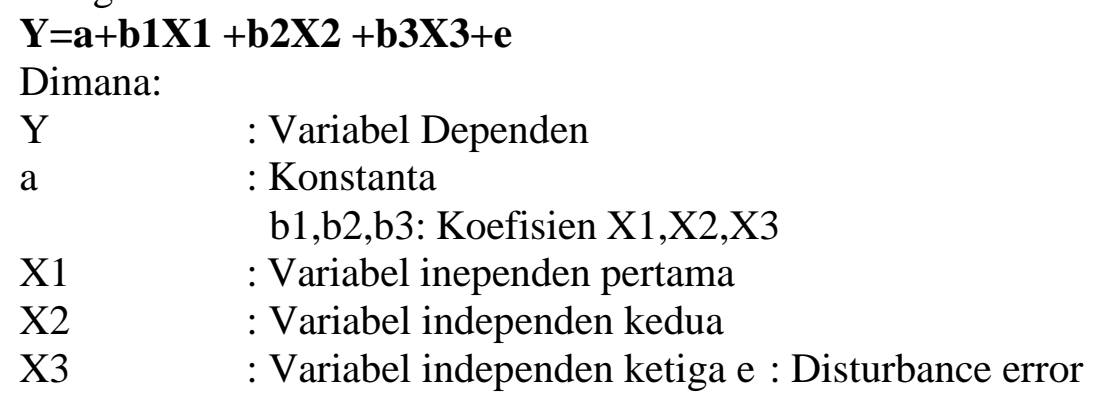

\section{Analisis Statistik Deskriptif}

Menurut Ghozali (2005) statistik deskriptif adalah teknik dalam statistika yang bertujuan untuk memberikan gambaran atau deskripsi suatu data. Dalam penelitian ini statistic yang digunakan adalah nilai rata-rata(mean), deviasi standar (standar deviation), nilai maksimun dan nilai minimum. Uji satistik deskriptif tersebut dilakukan terhadap semua variabel independen yangdigunakan dalam penelitian ini yaitu struktur modal, pertumbuhan perusahaan, dan ukuran perusahaan dan variabelmdependen yaitu nilai perusahaan. 


\section{Pengujian Asumsi Klasik}

1. Uji Normalitas

Uji normalitas bertujuan untuk menguji apakah dalam model regresi, variabel pengganggu atau residual memilki distribusi normal. Pengujian normalitas data dilakukan untuk menguji apakah dalam regresi, variabel terikat atau kedua-duanya memilki distribusi normal atau tidak. Model regresi yang baik adalah memilki distribusi data normal atau mendekati normal.

Grafik histogram maupun grafik normal plot memberikan pola distribusi yang menceng (skewness) ke kiri dan tidak normal. Sedangkan pada grafik normal plot terlihat titik-titik menyebar di sekitar garis diagonal, serta penyebarannya agak menjauh dari garis diagonal.

2. Uji Multikolonieritas

Uji multikolonieritas bertujuan untuk menguji apakah dalam model regresi ditemukan adanya korelasi antar variabel bebas (independen).

Untuk mendeteksi ada tidaknya multikolieritas dalam model regresi dapat dilihat dari tolerance value atau variance inflation factor (VIF). Sebagai syarat dasarnya dapat disimpulkan:

1. Jika nilai tolerance $>0,10$ dan nilai VIF $<0.10$ maka dapat disimpulkan bahwatidak ada multikolonieritas antar variabel indepenen dalam model regersi

2. Jika nilai tolerance $<0,10$ dan nilai VIF $>10$, maka dapat disimpulkan bahwa adaterjadi multikolonieritas antar variabel independen dalam model regresi.

3. Uji Autokorelasi

Untuk mengetahui ada atau tidaknya autokorelasi dalam suatu model regresi dilakukan pengujian dengan menggunakan uji Durbin- Waston (DW test). Pengambilan keputusan ada tidaknya autokorelasi:

1. Jika $\mathrm{d}<\mathrm{dl}$, berarti terdapat autokorelasi positif

2. Jika d $>$ (4-dl), berarti terdapat autokorelasi negatif

3. Jika du $<\mathrm{d}<(4-\mathrm{du})$, berarti tidak dapat korelasi

4. Jika dl $<\mathrm{d}<\mathrm{du}$ atau (4-du), berarti tidak dapat disimpulkan.

\section{Uji Heteroskedastisitas}

Deteksi ada tidaknya heteroskedasitas dapat dilakukan dengan melihat ada tidaknya pola tertentu pada grafik scatterplot antara SRESID dan SPRED dimana sumbu Y adalah Y yang telah dipreediksi, dan sumbu $\mathrm{X}$ adalah residual yang telah studenitized. Dasar analisanya:

1. Jika ada pola tertentu, seperti titik-titik yang ada membentuk pola tertentu yang teratur (bergelombang, melebar, dan kemudian menyempit) maka mengindikasikan telah terjadi heterokedasitas.

2. Jika tidak ada pola jelas, serta titik-titik menyabar diaats dan dibawah angka nol pada sumbu Y, maka dalam model regresi tidak terjadi masalah heteroskedastisitas.

\section{Pengujian Hipotesis}

\section{Uji Koefisien Determinasi $\left(\mathrm{R}^{2}\right)$}

Analisis determinasi dalam regresi linear berganda digunakan untuk mengetahui presentase sumbangan pengaruh variabel independen secara serentak terhadap variabel dependen. Koefisien ini menunjukkan seberapa besar presentase variasi variabel independen yang digunakan dalam model mampu menjelaskan variasi variabel $\mathrm{R}^{2}=0$ maka tidak ada sedikitpun persentase sumbangan pengaruh yang diberikan variabel independen terhadap variabel dependen atau variasi variabel independen yang digunakan dalm model mampu menjelaskan sedikitpun variasi variabel dependen. 
Sebaliknya $\mathrm{R}^{2}=1$ maka peresentase sumbangan pengaruh yang diberikan variabel independen terhadap variabel dependen adalah sempurna atau variasi variabel independen yang digunakandalam model mampu menjelaskan $100 \%$ variasi variabel dependen.

2. Uji t

Pengujian terhadap hasil regresi dilakukan dengan menggunakan uji-t pada derajat keyakinan 95\% atau $\alpha=5 \%$. Langkah-langkahnya sebagai berikut:

1. Menentukan Formula Hipotesis

a. $\mathrm{H} 0: \mathrm{b} 1=0$ : Struktu modal tidak berpengaruh positif dan signifikan terhadap nilai perusahaan pada perusahaan barang konsumsi yang terdaftar di Bursa Efek Indonesia.

b. Ha $: b 1 \neq 0:$ Struktur modal berpengaruh positif dan signifikan terhadap nilai perusahaan pada perusahaan barang konsumsi yang terdaftar di Bursa Efek Indonesia.

c. $\mathrm{H} 0: \mathrm{b} 2=0$ : Pertumbuhan perusahaan tidak berpengaruh positif dan signifikan terhadap nilai perusahaan pada perusahaan barang konsumsi yangterdaftar di Bursa Efek Indonesia.

d. Ha : $\mathrm{b} 2 \neq 0$ : Pertumbuhan perusahaan berpengaruh positif dan signifikan terhadap nilai perusahaan pada perusahaan barang konsumsi yang terdaftar di Bursa Efek Indonesia.

e. $\mathrm{H} 0: \mathrm{b} 3=0$ : Ukuran perusahaan tidak berpengaruh positif dan signifikan terhadap nilai perusahaan pada perusahaan barang konsumsi yang terdaftar di Bursa Efek Indonesia.

f. Ha : b3 $\neq 0$ : Ukuran perusahaan berpengaruh positif dan signifikan terhadap nilai perusahaan pada perusahaan barang konsumsi yang terdaftar di Bursa Efek Indonesia.

2. Membandingkan probabilitas tingkat kesalahan $\mathrm{t}$ hitung dengan tingkat signifikansi tertentu.

3. Membuat keputusan Pengambilan keputusan uji hipotesis secara parsial didasarkan pada nilai probabilitas yang didapatkan dari hasil pengolahan data melalui program SPSS sebagai berikut :

Jika signifikansi $\mathrm{t} \geq 0.05$ maka H0 diterima.Jika signifikansi $\mathrm{t}<0.05$ maka H0 ditolak. Jika $\mathrm{t}$ hitung $\leq \mathrm{t}$ tabel maka $\mathrm{HO}$ diterima.

Jika t hitung > t tabel maka H0 ditolak.

\section{Uji F}

Uji $\mathrm{F}$ dilakukan untuk menguji apakah semua variabel independen yang diamati berpengaruh signifikan terhadap variabel dependen.

1. Merumuskan Hipotesis

$\mathrm{H} 0: \mathrm{b} 1: \mathrm{b} 2: \mathrm{b} 3=0$ artinya struktur modal, pertumbuhan perusahaan dan ukuran perusahaan tidak berpengaruh positif secara simultan terhadap nilai perusahaan pada perusahaan barang konsumsi yang terdaftar di BEI.

Ha : b1 : b2 : b3 $\neq 0$ artinya struktur modal, pertumbuhan perusahaan dan ukuran perusahaan berpengaruh positif secara simultan terhadap nilai perusahaan pada perusahaan barang konsumsi yang terdaftar di BEI.

2. Menentukan sampel yang digunakan.

3. Menentukan tingkat signifikansi $(\alpha)$ yang digunakan, $\alpha=5 \%$ program analisis regression linear.

4. Membuat keputusan. 


\section{HASIL DAN PEMBAHASAN}

\section{Uji Normalitas}

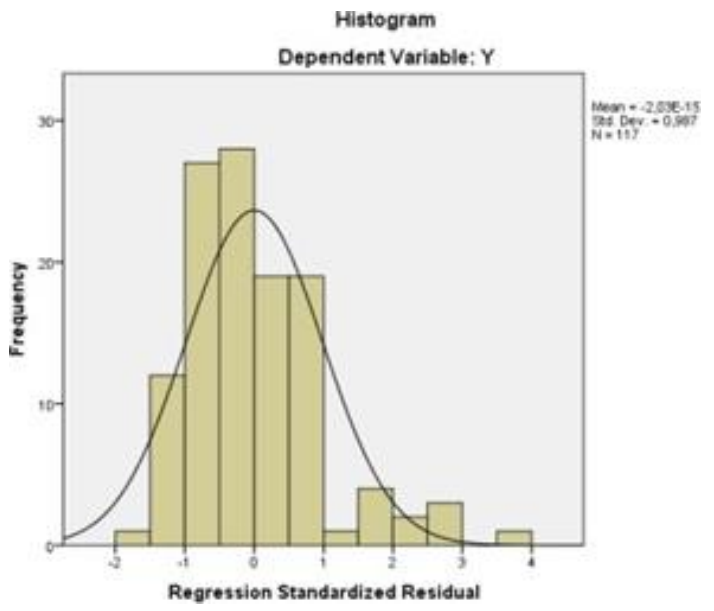

Gambar 1. Hasil Uji Normalitas Data dengan Grafik Histogram Sumber : Hasil Output SPSS v.22 (Data Diolah)

Pada gambar terlihat bahwa variabel terikat (Y) yaitu Nilai Perusahaan mempunyai distribusi normal. Dapat dilihat bahwa gambar histogram telah berbentuk lonceng dan tidak menceng ke kiri atau ke kanan.

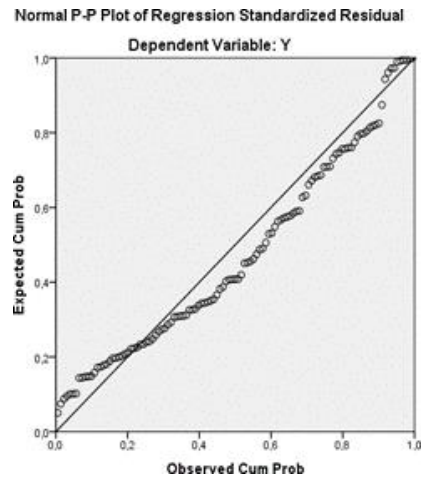

Gambar 2. Hasil Uji Normalitas Data dengan Grafik P-P Plot Sumber : Hasil Output SPSS v.22 (Data Diolah)

Pada gambar diatas dapat dilihat bahwa titik-titik menyebar disekitar garis diagonal dan tidak jauh dari garis diagonal. Hal ini menunjukkan bahwa data telahterdistribusi normal.

\section{Uji Multikolonieritas}

\section{Coefficientsa}

\begin{tabular}{|c|c|c|c|c|c|c|c|c|}
\hline \multirow[t]{2}{*}{ Model } & \multicolumn{2}{|c|}{$\begin{array}{l}\text { Instandardized } \\
\text { Coefficients }\end{array}$} & \multirow{2}{*}{\begin{tabular}{|c|}
$\begin{array}{l}\text { Standardi zed } \\
\text { Coef ficients }\end{array}$ \\
Beta
\end{tabular}} & \multirow[t]{2}{*}{$\mathrm{t}$} & \multirow[t]{2}{*}{ Sig. } & \multicolumn{3}{|c|}{ Collinearity Statistics } \\
\hline & $\mathrm{B}$ & Std. Error & & & & Toler ance & VIF & \\
\hline $\begin{array}{l}\text { (Consta } \\
\text { nt) }\end{array}$ & $-2,866$ & 1,129 & & $-2,538$ & ,012 & & & \\
\hline. $\mathrm{X} 1$ &,- 059 & ,269 &,- 019 &,- 219 & ,827 & ,990 & &, 010 \\
\hline $\mathrm{X} 2$ & 1,058 &, 530 &, 173 & 1,995 & ,048 & ,995 & & 005 \\
\hline , 172 & 041 & 366 & 4,196 & 000 & 986 & & ,014 & \\
\hline
\end{tabular}


a. Dependent Variable: Y

Dapat dilihat bahwa Tolerance Value $>0,10$ dan VIF $<10$, sehingga dapat disimpulkan diantara variabel bebas (independen) tersebut tidak terdapat hubungan multikolonieritas. Dari hasil uji ini maka dapat disimpulkan bahwa semua variabel bebas yang digunakan dalam penelitian ini lolos uji gejala multikolonieritas.

\section{Uji Autokorelasi}

\section{Model Summaryb}

\begin{tabular}{|l|l|l|l|l|l|}
\hline $\begin{array}{l}\text { Mo } \\
\text { del }\end{array}$ & \multicolumn{1}{|c|}{$\begin{array}{c}\text { R } \\
\text { Square }\end{array}$} & $\begin{array}{l}\text { Adjusted R } \\
\text { Square }\end{array}$ & Std. Error of the Estimate & Durbin- Watson \\
\hline 1 & , 393a & 154 &, 132 & 1,465699 & 1,782 \\
\hline
\end{tabular}

a. Predictors: (Constant), X3, X2, X1

ь. Dependent Variable: Y

Dapat dilihat bahwa nilai Durbin-Watson (DW) sebesar 1,782. Nilai ini akan dibandingkan dengan nilai tabel menggunakan $\alpha=5 \%, n=39, k=3$. Berdasarkan tabel DW didapatkan nilai batas bawah $(\mathrm{dL})=1,3283$ dan nilai batas atas $(\mathrm{dU})=1,6575$. Jadi dapat dihitung 4-dL=2,6717 dan 4-dU=2,3425. Dengan demikian nilai dU yakni $1,6575<\mathrm{DW}$ yakni 1,782<4-dU yakni 2,3425. Dapat disimpulkan bahwa tidak terdapat autokorelasi pada data tersebut.

\section{Uji Heteroskedastisitas}

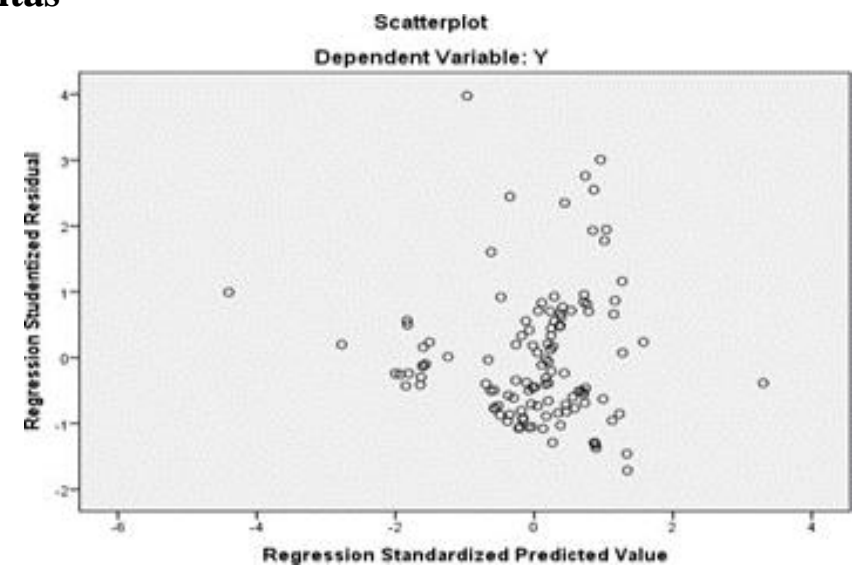

Terlihat titik-titik menyebar secara acak serta tersebar dengan baik diatas maupun dibawah angka 0 pada sumbu Y. maka dapat diambil kesimpulan bahwa tidak terdapat gejala heteroskedastisitas pada model regresi yang digunakan.

\section{Uji Linear Berganda}

\section{Coefficients ${ }^{\mathbf{a}}$}

\begin{tabular}{|l|l|l|l|l|l|}
\hline Model & \multicolumn{2}{|l|}{$\begin{array}{l}\text { nnstandardized } \\
\text { Coefficients }\end{array}$} & $\begin{array}{l}\text { Standar dized } \\
\text { Coefficients }\end{array}$ & t & Sig. \\
\cline { 2 - 4 } & B & Std.Error & Beta & & \\
\hline Constant) & $-2,866$ & 1,129 & & $-2,538$ &, 012 \\
\hline
\end{tabular}




\begin{tabular}{|r|r|r|r|r|r|}
\hline $\mathrm{X} 1$ &,- 059 &, 269 &,- 019 &,- 219 &, 827 \\
\hline $\mathrm{X} 2$ & 1,058 &, 530 &, 173 & 1,995 &, 048 \\
\hline $\mathrm{X} 3$ &, 172 &, 041 &, 366 & 4,196 &, 000 \\
\hline
\end{tabular}

a. Dependent Variable: Y

Berdasarka tabel tersebut, maka dapat disusun persamaan regresi sebagai berikut:

$\mathbf{Y}=\mathbf{a}+\mathbf{b} 1 \mathrm{X} 1+\mathbf{b} 2 \mathrm{X} 2+\mathbf{b} 3 \mathbf{X} 3+\mathrm{e}$

Nilai Perusahaan $=-2,866-0,059 \mathrm{X} 1+1,058 \mathrm{X} 2+0,172 \mathrm{X} 3+\mathrm{e}$

Berdasarkan persamaan regresi tersebut dapat dianalisis pengaruh masing-masing variabel independen terhadap variabel dependen (nilai perusahaan) yaitu:

1. Nilai konstanta adalah $-2,866$ artinya jika variabel struktur modal, pertumbuhan perusahaan dan ukuran perusahaan bernilai 0, maka nilai perusahaan sebesar konstanta yaitu $-2,866$ atau $-286,6 \%$.

2. Nilai koefisien Struktur Modal (X1) adalah -0,059 artinya setiap kenaikan struktur modal sebesar $1 \%$ akan menurunkan nilai perusahaan sebesar 5,9\%.

\section{PENGUJIAN HIPOTESIS}

\section{Uji Determinasi $\left(\mathbf{R}^{2}\right)$}

Hasil Uji Koefisien Determinasi

\section{Model Summaryb}

\begin{tabular}{|l|l|l|l|l|}
\hline Model & $\mathrm{R}$ & $\mathrm{R}$ Square & $\begin{array}{l}\text { djusted R } \\
\text { Square }\end{array}$ & Std. Error of the Estimate \\
\hline 1 & $393^{\mathrm{a}}$ &, 154 &, 132 & 1,465699 \\
\hline
\end{tabular}

Predictors: (Constant), X3, X2, X1

a. Dependent Variable: Y

Sumber : Hasil Output SPSS v.22 (Data Diolah)

Berdasarkan tabel diperoleh nilai koefisien determinasi (Adjusted R Square) sebesar 0,132 atau 13,2\% artinya variabel independen (struktur modal, pertumbuhan perusahaan dan ukuran perusahaan) secara simultan mempengaruhi variabel dependen yaitu Nilai Perusahaan sebesar $13,2 \%$. Sedangkan sisanya $86,8 \%(1-0,132)$ dipengaruhi oleh variabel lain yang tidak terungkap atau tidak diteliti dalam penelitian ini.

\section{Uji T}

Hasil Uji T

\section{Coefficientsa}

\begin{tabular}{|c|l|l|l|l|l|l|}
\hline Model & \multicolumn{2}{|c|}{$\begin{array}{c}\text { Unstandardized } \\
\text { Coefficients }\end{array}$} & $\begin{array}{l}\text { Standardized } \\
\text { Coefficie } \\
\text { nts }\end{array}$ & T & \multicolumn{2}{|c|}{ Sig. } \\
\cline { 2 - 6 } & B & $\begin{array}{l}\text { Std. } \\
\text { Error }\end{array}$ & Beta & & \\
\hline (Constant) & $-2,866$ & 1,129 & & $-2,538$ &, 012 \\
\hline
\end{tabular}




\begin{tabular}{|l|l|l|l|l|l|l|}
\hline 1 & $\mathrm{X} 1-, 059$ &, 269 &,- 019 &,- 219 &, 827 \\
\hline & $\mathrm{X} 2$ & 1,058 &, 530 &, 173 & 2,995 &, 048 \\
\hline & $\mathrm{X} 3,172$ &, 041 &, 366 & 4,196 &, 000 \\
\hline
\end{tabular}

a. Dependent Variable: Y

Sumber : Hasil Output SPSS v.22 (Data Diolah)

\section{Uji F}

Hasil Uji F

\section{ANOVAa}

\begin{tabular}{|l|l|l|r|l|l|l|}
\hline \multicolumn{2}{|l|}{ Model } & $\begin{array}{l}\text { Sum of } \\
\text { Squares }\end{array}$ & df & $\begin{array}{l}\text { Mean } \\
\text { Square }\end{array}$ & F & Sig. \\
\cline { 1 - 5 } 1 & Regression & 44,242 & 3 & $14,7476,865$ &, $000^{\mathrm{b}}$ \\
\cline { 1 - 5 } & Residual & 242,755 & 113 & 2,148 & & \\
\hline & Total & 286,997 & 116 & & \\
\hline
\end{tabular}

a. Dependent Variable: $\mathrm{Y}$

b. Predictors: (Constant), X3, X2, X1

Sumber : Hasil Output SPSS v.22 (Data Diolah)

Berdasarkan tabel diatas menunjukkan bahwa nilai sig dari Uji anova ini adalah sebesar 0,000 dimana $0,000<0,05$ dan $\mathrm{F}_{\text {hitung }} 6,865>\mathrm{F}_{\text {tabel }} 2,85$ maka $\mathrm{H}_{4}$ diterima, artinya struktur modal, pertumbuhan perusahaan dan ukuran perusahaan berpengaruh positif dan signifikan secara simultan terhadap nilai perusahaan.

\section{Pembahasan}

\section{Pengaruh Struktur Modal terhadap Nilai Perusahaan pada Perusahaan Barang} Konsumsi yang Terdaftar di BEI

Hasil penelitian ini menunjukkan bahwa struktur modal tidak memiliki pengaruh yang positif dan signifikan terhadap nilai perusahaan pada perusahaan barang konsumsi yang terdaftar di BEI tahun 2017 - 2019. Hal ini dibuktikan dari hasil pengujian hipotesis yang menunjukkan bahwa nilai thitung $-0,219<\mathrm{t}_{\text {tabel }} 2,028$ pada taraf signifikansi $0,827>0,05$. Hasil penelitian ini membuktikan bahwa hipotesis alternative (Ha) ditolak dan hipotesis nol (Ho) diterima atau tidak adanya pengaruh positif yang signifikan dari struktur modal terhadap nilai perusahaan. Hal ini berarti bahwa perkembangan kebijakan struktur modal yang dilakukan oleh perusahaan tidak mempengaruhi penilaian investor terhadap kinerja perusahaan. Dengan demikian struktur modal bukan merupakan prediktor yang baik untuk menjelaskan nilai perusahaan.

\section{Pengaruh Pertumbuhan Perusahaan terhadap Nilai Perusahaan pada Perusahaan Barang Konsumsi yang Terdaftar di BEI}

Hasil penelitian ini menunjukkan bahwa pertumbuhan perusahaan berpengaruh secara positif dan signifikan terhadap nilai perusahaan pada perusahaan barang konsumsi yang terdaftar di BEI periode 2017-2019, yang dapat dilihat dari nilai koefisien regresi pertumbuhan perusahaan sebesar 1,058 atau 105,8\% dengan signifikansi 0.048 , yang berarti bahwa setiap adanya penambahan pertumbuhan perusahaan sebesar $1 \%$ satuan akan berpengaruh pada peningkatan nilai perusahaan sebesar 105,8\%. 
Hasil penelitian ini menunjukkan bahwa pertumbuhan perusahaan berpengaruh secara positif dan signifikan dibuktikan dari nilai $t_{\text {hitung }} 2995>t_{\text {tabel }} 2,028$ pada taraf signifikansi $0,048<0,05$. Hasil penelitian ini membuktikan bahwa hipotesis alternatif (Ha) diterima dan hipotesis nol (Ho) ditolak atau adanya pengaruh positif yang signifikan dari pertumbuhan perusahaan terhadap nilai perusahaan. Dengan demikian pertumbuhan perusahaan merupakan prediktor yang baik untuk menjelaskan nilai perusahaan.

\section{Pengaruh Ukuran Perusahaan terhadap Nilai Perusahaan pada Perusahaan Barang Konsumsi yang Terdaftar di BEI}

Hasil penelitian ini menunjukkan bahwa ukuran perusahaan berpengaruh secara positif dan signifikan terhadap nilai perusahaan pada perusahaan barang konsumsi yang terdaftar di BEI periode 2017-2019, yang dapat dilihat dari nilai koefisien regresi pertumbuhan perusahaan sebesar 0,172 atau $17,2 \%$ dengan signifikansi 0.000 , yang berarti bahwa setiap adanya penambahan pertumbuhan perusahaan sebesar $1 \%$ satuan akan berpengaruh pada peningkatan nilai perusahaan sebesar $17,2 \%$.

Hasil penelitian ini menunjukkan bahwa ukuran perusahaan berpengaruh secara positif dan signifikan dibuktikan dari nilai thitung $4,196>t_{\text {tabel }} 2,028$ pada taraf signifikansi $0,000<$ 0,05 . Hasil penelitian ini membuktikan bahwa hipotesis alternatif (Ha) diterima dan hipotesis nol (Ho) ditolak atau adanya pengaruh positif yang signifikan dari ukuran perusahaan terhadap nilai perusahaan. Dengan demikian ukuran perusahaan merupakan prediktor yang baik untuk menjelaskan nilai perusahaan.

\section{Pengaruh Struktur Modal, Pertumbuhan Perusahaan dan Ukuran Perusahaan} terhadap Nilai Perusahaan pada Perusahaan Barang Konsumsi yang Terdaftar di BEI

Hasil penelitian ini telah dibuktikan bahwa secara bersama-sama struktur modal, pertumbuhan perusahaan, dan ukuran perusahaan berpengaruh signifikan terhadap nilai perusahaan. Hal ini diperlihatkan oleh hasil pengujian hipotesis yang menunjukkan bahwa nilai $F_{\text {hitung }} 6,865>F_{\text {tabel }} 2,85$ pada taraf signifikansi $0,000<0,05$. Dengan demikian bahwa secara bersama-sama, struktur modal, pertumbuhan perusahaan dan ukuran perusahaan mampu menjelaskan dengan baik nilai perusahaan. Hal ini berarti bahwa perkembangan struktur modal yang diikuti oleh pertumbuhan perusahaan dan peningkatan ukuran perusahaan akan memberikan efek yang positif dalam meningkatkan nilai perusahaan pada perusahaan barang konsumsi yang terdaftar di Bursa Efek Indonesia Tahun 2017-2019.

\section{KESIMPULAN DAN SARAN}

\section{Kesimpulan}

1. Struktur modal tidak berpengaruh positif dan signifikan terhadap nilai perusahaan pada perusahaan barang konsumsi yang terdaftar di BEI, karena nilai $t_{\text {hitung }}-0,219<\mathrm{t}_{\text {tabel }} 2,028$ pada taraf signifikansi $0,827>0,05$. Maka $\mathrm{H}_{1}$ ditolak.

2. Pertumbuhan perusahaan berpengaruh positif dan signifikan terhadap nilai perusahaan pada perusahaan barang konsumsi yang terdaftar di BEI, karena nilai $t_{\text {hitung }} 2995>t_{\text {tabel }}$ 2,028 pada taraf signifikansi $0,048<0,05$. Maka $\mathrm{H}_{2}$ diterima.

3. Ukuran perusahaan berpengaruh positif dan signifikan terhadap nilai perusahaan pada perusahaan barang konsumsi yang terdaftar di BEI, karena nilai thitung $4,196>t_{\text {tabel }} 2,028$ pada taraf signifikansi $0,000<0,05$. Maka $\mathrm{H}_{3}$ diterima.

4. Struktur modal, pertumbuhan perusahaan dan ukuran perusahaan berpengaruh signifikan secara simultan terhadap nilai perusahaan pada perusahaan barang konsumsi yang terdaftar di BEI, karena nilai $F_{\text {hitung }} 6,865>F_{\text {tabel }} 2,85$ pada taraf signifikansi $0,000<$ 0,05. Maka $\mathrm{H}_{4}$ diterima. 


\section{Saran}

Bagi peneliti selanjutnya supaya melakukan penelitian dengan subjek penelitian yang lebih besar dan lebih beragam misalnya dengan menggunakan perusahaan manufaktur atau seluruh perusahaan yang ada di Bursa Efek Indonesia.

\section{DAFTAR PUSTAKA}

Brigham, E.F. dan J. Houston. 2001. Manajemen Keuangan. Edisi Kedelapan Buku II. Jakarta: Erlangga.

Eka Lestari, Putu. 2010. Pengaruh Struktur Modal, Kepemilikan Manajerial dan Ukuran Perusahaan Terhadap Nilai Perusahaan pada Perusahaan Manufaktur di BEI. Skripsi. Fakultas Ekonomi Universitas Udayana.

Indriyani, Eka. 2017. Pengaruh Ukuran Perusahaan Dan Profitabilitas Terhadap Nilai Perusahaan. Ilmu Akuntansi, 10(2), 333-348.

Mardiyati, Umi dan Ria Putri. 2012. Pengaruh Kebijakan Dividen, Kebijakan Hutang dan Profitabilitas Terhadap Nilai Perusahaan Manufaktur yang Terdaftar di BEI. Riset Manajemen Sains indonesia, 3(1), 1-17.

Sujoko dan Ugy Soebiantoro. 2007. Pengaruh Struktur Kepemilikan Saham, Leverage, Faktor Interen dan Faktor Eksteren Terhadap Nilai Perusahaan. Jurnal Manajemen dan Kewirausahaan. Vol. 9, No.1.

Kasmir. 2012. Analisis Laporan Keuangan. Jakarta: PT. Raja Grafindo Persada. Suwardika, I. N. A., \& Mustanda, I. K. 2017. Pengaruh Leverage, Ukuran Perusahaan,

Pertumbuhan Perusahaan, dan Profitabilitas terhadap Nilai Perusahaan Pada Perusahaan Properti. E-Jurnal Manajemen Unud, 6(3), 1248- 1277.

Suwito dan Herawaty. 2005. Pengaruh Leverage dan Ukuran Perusahaan Terhadap Harga Saham di BEI. Jurnal Akuntansi dan Keuangan. Vol.5, No.1.

Wijaya, B. I. Dan Panji. 2015. Pengaruh Profitabilitas Terhadap Nilai Perusahaan (Kebijakan Deviden dan Kesempatan Investasi Sebagai Variabel Mediasi). Jurnal Manajemen. Vol.4, No.12.

Safrida, Eli. 2008. Pengaruh Struktur Modal dan Pertumbuhan Perusahaan terhadap Nilai Perusahaan pada Perusahaan Manufaktur di BEI. Thesis.Medan: Universitas Sumatera Utara.

Salvatore, Dominick. 2005. Ekonomi Manajerial. Buku II. Jakarta: Salemba Empat. 